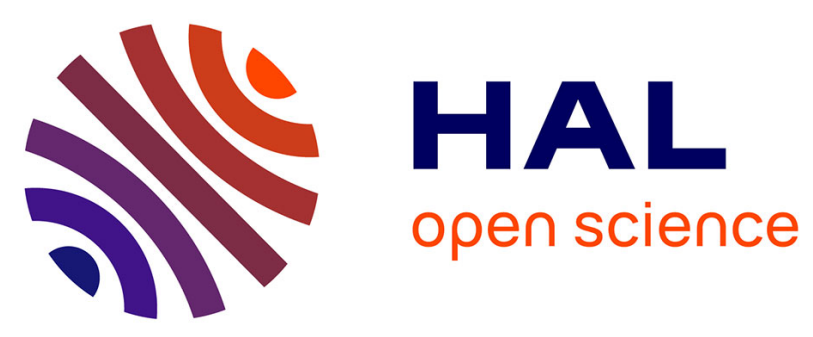

\title{
Effect of climate change, CO2 trends, nitrogen addition, and land-cover and management intensity changes on the carbon balance of European grasslands
}

Jinfeng Chang, Philippe Ciais, Nicolas Viovy, Nicolas Vuichard, Mario Herrero, Petr Havlík, Xuhui Wang, Benjamin Sultan, Jean-François Soussana

\section{- To cite this version:}

Jinfeng Chang, Philippe Ciais, Nicolas Viovy, Nicolas Vuichard, Mario Herrero, et al.. Effect of climate change, $\mathrm{CO} 2$ trends, nitrogen addition, and land-cover and management intensity changes on the carbon balance of European grasslands. Global Change Biology, 2016, 22 (1), pp.338-350. 10.1111/gcb.13050 . hal-01233436

\section{HAL Id: hal-01233436 \\ https://hal.sorbonne-universite.fr/hal-01233436}

Submitted on 25 Nov 2015

HAL is a multi-disciplinary open access archive for the deposit and dissemination of scientific research documents, whether they are published or not. The documents may come from teaching and research institutions in France or abroad, or from public or private research centers.
L'archive ouverte pluridisciplinaire HAL, est destinée au dépôt et à la diffusion de documents scientifiques de niveau recherche, publiés ou non, émanant des établissements d'enseignement et de recherche français ou étrangers, des laboratoires publics ou privés. 
1 Title: Effect of climate change, $\mathrm{CO}_{2}$ trends, nitrogen addition, land cover and management

2 intensity changes on the carbon balance of European grasslands

$4 \quad$ Running head: Attribution the European grasslands NBP trend

6 Jinfeng Chang ${ }^{1,2}$, Philippe Ciais ${ }^{1}$, Nicolas Viovy ${ }^{1}$, Nicolas Vuichard ${ }^{1}$, Mario Herrero ${ }^{3}$, Petr

7 Havlík$^{4}$, Xuhui Wang ${ }^{5,6}$, Benjamin Sultan ${ }^{2}$, Jean-François Soussana ${ }^{7}$

8

91 Laboratoire des Sciences du Climat et de l'Environnement, UMR8212, CEA-CNRS-UVSQ,

1091191 Gif-sur-Yvette, France

112 Sorbonne Universités (UPMC, Univ Paris 06)-CNRS-IRD-MNHN, LOCEAN/IPSL, 4 place

12 Jussieu, 75005 Paris, France

133 Commonwealth Scientific and Industrial Research Organisation, Agriculture Flagship, St.

14 Lucia, QLD 4067, Australia

154 Ecosystems Services and Management Program, International Institute for Applied Systems 16 Analysis, 2361 Laxenburg, Austria

175 Laboratoire de Météorologie Dynamique, Institute Pierre Simon Laplace, 75005 Paris 18 France

196 Sino-French Institute of Earth System Sciences, College of Urban and Environmental

20 Sciences, Peking University, 100871 Beijing China

217 INRA, Grassland Ecosystem Research Unit, UREP, 63100 Clermont-Ferrand, France 
23 Correspondence to: J.F. Chang e-mail: jinfeng.chang@locean-ipsl.upmc.fr Tel: +33 16908

247712 Fax: +33169087716

25

26 Keywords: ORCHIDEE-GM, European grassland, carbon balance, management intensity,

27 climate change, land-cover change

28

29 Paper type: Primary Research Articles

30 
Several lines of evidence point to European managed grassland ecosystems being a sink of carbon. In this study, we apply ORCHIDEE-GM a process-based carbon cycle model that describes specific management practices of pastures and the dynamics of carbon cycling in response to changes in climatic and biogeochemical drivers. The model is used to simulate changes in the carbon balance (i.e., Net Biome Production, NBP) of European grasslands over $1991-2010$ on a $25 \mathrm{~km} \times 25 \mathrm{~km}$ grid. The modeled average trend of NBP is $1.8-2.0 \mathrm{~g} \mathrm{C} \mathrm{m}^{-2}$ $\mathrm{yr}^{-2}$ during the past two decades. Attribution of this trend suggests management intensity as the dominant driver explaining NBP trends in the model $(36 \%-43 \%$ of the trend due to all drivers). A major change in grassland management intensity has occurred across Europe resulting from reduced livestock numbers. This change has 'inadvertently' enhanced soil C sequestration and reduced $\mathrm{N}_{2} \mathrm{O}$ and $\mathrm{CH}_{4}$ emissions by 1.2 - $1.5 \mathrm{Gt} \mathrm{CO}_{2}$-equivalent, offsetting more than $7 \%$ of greenhouse gas emissions in the whole European agricultural sector during the period 1991-2010. Land-cover change, climate change and rising $\mathrm{CO}_{2}$ also make positive and moderate contributions to the NBP trend (between $24 \%$ and $31 \%$ of the trend due to all drivers). Changes in nitrogen addition (including fertilization and atmospheric deposition) is found to have only marginal net effect on NBP trends. However, this may not reflect reality because our model has only a very simple parameterization of nitrogen-effects on photosynthesis. The sum of NBP trends from each driver is larger than the trend obtained when all drivers are varied together, leaving a residual - non-attributed - term $(22 \%-26 \%$ of the trend due to all drivers) indicating negative interactions between drivers. 


\section{Introduction}

Grassland is not a natural vegetation type in Europe. Europe's grasslands were created and managed to feed livestock for producing meat and dairy products (so-called pasture). These grasslands are mowed for forage production and grazed by ruminant animals, often within the same farm, although in regions of intensive livestock production, animals are also fed substantial additional amounts of crop feedstuff products. Meanwhile, nitrogen-rich mineral and organic fertilizers (manure/slurry) are commonly applied to European grasslands to sustain meat and dairy production. The frequency and intensity of these agricultural practices, combined with climate change, are expected to strongly impact the carbon (C) balance of grasslands in Europe (Soussana et al., 2007).

The annual $\mathrm{C}$ balance of managed grassland ecosystems (also called net biome production, NBP; here using the definition proposed by Schulze \& Heimann, 1998; Buchmann \& Schulze, 1999; and Chapin et al., 2006) must account for not only the fluxes of $\mathrm{CO}_{2}$ exchanged with the atmosphere (net ecosystem production, $N E P$ ), but also the land-atmosphere $\mathrm{CO}_{2}$ fluxes caused by lateral carbon import and export due to management and other processes (e.g., C export to rivers and groundwater). NEP is determined by the difference between net primary productivity (NPP) and ecosystem-level heterotrophic respiration $\left(R_{h}\right)$. NPP, indicating the C incorporated into plant biomass, is known to be sensitive to climate (Melillo et al., 1993), atmospheric $\mathrm{CO}_{2}$ concentration (e.g., Ainsworth \& Long, 2005) and nitrogen availability (Le Bauer \& Treseder, 2008; Xia \& Wan, 2008). $\mathrm{R}_{\mathrm{h}}$ is also controlled by climate (Rustad et al., 2001) as well as by organic $\mathrm{C}$ and nitrogen availability, and micro-environmental conditions (soil physical and chemical properties such as clay content, $\mathrm{pH}$, etc), while organic $\mathrm{C}$ input to 
$R_{h}$ (including above and belowground litter) is determined both by NPP, and by C input (as manure) and exported as harvested biomass or ingested by grazing animals.

The amount of $\mathrm{C}$ exported from a grassland ecosystem depends on the grass consumed by ruminant livestock. According to the FAOstat agricultural statistics, during the period 19912010, a more than $17 \%$ reduction of livestock numbers occurred across Europe. This reduced the requirement for grass forage; at the same time grassland potential productivity was increasing (Chang et al., 2015a). These changes affected the ecosystem C balance, decreasing $\mathrm{C}$ export and increasing litter-fall to soils. Meanwhile, according to the harmonized high resolution land-cover change data set HILDA (Fuchs et al., 2013), the grassland area increased by $3.7 \%$ in the 30 European countries of the EU28 plus Norway and Switzerland. This figure includes concurrent loss and creation of grasslands by $5.8 \%$ and $9.5 \%$ of total grassland area in 1991, respectively, but with significant regional differences (EEA, 2005, pp. 47-53). The stronger relative reduction of livestock numbers compared to that of grassland area suggests an overall trend towards less intensive pasture usage.

A significant net $\mathrm{C}$ sequestration (a positive NBP of $15 \pm 7 \mathrm{~g} \mathrm{C} \mathrm{m}^{-2} \mathrm{yr}^{-1}$ ) by grassland ecosystems of the 30 European countries during the period 1961-2010 was estimated in a previous study, using the process-based biogeochemical model ORCHIDEE-GM, which has an explicit and rather detailed representation of grassland management (Chang et al., 2015b). ORCHIDEE-GM simulates a significant increase of NBP with time during the past five decades (NBP linear trend of $0.25 \pm 0.08 \mathrm{~g} \mathrm{C} \mathrm{m}^{-2} \mathrm{yr}^{-2}, \mathrm{P}=0.26$ ) with the rate of increase being much larger after $1990\left(1.83 \pm 0.30 \mathrm{~g} \mathrm{C} \mathrm{m}^{-2} \mathrm{yr}^{-2}, \mathrm{P}=0.07\right)$ than before that date $(-0.25 \pm 0.15$ $\left.\mathrm{g} \mathrm{C} \mathrm{m}^{-2} \mathrm{yr}^{-2}, \mathrm{P}=0.55\right)$. This acceleration of $\mathrm{C}$ sequestration can be attributed to changes in climate, $\mathrm{CO}_{2}$ concentration, nitrogen atmospheric deposition, land-cover change, and to changes in management drivers, e.g., fertilization and decreasing grazing intensity, through 
100 decreased livestock numbers (Chang et al., 2015b). Yet, the quantitative contribution of these 101 drivers and their interactions, to the observed NPP and NBP trends are not clearly understood.

102 In this study, we use the ORCHIDEE-GM Version 2.1 managed grassland model to analyze 103 the overall trend of NBP of European grasslands during the past two decades. We separate the 104 effects of changes in management, i.e., grassland management intensity (including 105 abandonment, grazing intensity decrease or intensification, and change in fertilizer usage), 106 and new grassland establishment (land-cover change) from the effects of observed external 107 drivers, i.e., climate change, rising $\mathrm{CO}_{2}$ and nitrogen deposition. 
Model description

ORCHIDEE is a process-based ecosystem model for simulating carbon cycling in ecosystems, and water and energy fluxes from site-level to global scale (Krinner et al., 2005; Ciais et al., 2005; Piao et al., 2007). ORCHIDEE-GM (Chang et al., 2013) is a version of ORCHIDEE specifically developed to study grassland management. It incorporates a grassland module from the PaSim model (Reido et al., 1998; Vuichard et al., 2007a,b; Graux et al., 2011). ORCHIDEE-GM Version 1 was evaluated and some of its parameters calibrated using eddy covariance NEE and biomass measurements from 11 European grassland sites representative of a range of management practices. The model simulated the average NBP of these managed grasslands as $37 \pm 30 \mathrm{~g} \mathrm{C} \mathrm{m}^{-2} \mathrm{yr}^{-1}, \mathrm{P}<0.01$; Chang et al., 2013). At continental scale, ORCHIDEE-GM Version 2.1 was first applied over Europe to calculate the spatial pattern, long-term evolution and interannual variability of potential productivity (potential productivity is the productivity resulting from the optimal management regime that maximizes livestock densities; Chang et al., 2015a). Chang et al. (2015a) further added a new parameterization to describe an adaptive management strategy whereby farmers react to a climate-driven change of previous-year productivity. Though a full nitrogen cycle is not included in ORCHIDEE-GM, the positive effect of nitrogen addition on grass photosynthesis, and thus on subsequent ecosystem carbon balances, is parameterized with a simple empirical function calibrated from literature estimates (Chang et al., 2015a). In a recent study, grasslands during the past five decades, indicating an enhancement of the $\mathrm{C}$ sink over the 
period 1991-2010 (with an NBP increasing rate of $1.83 \pm 0.30 \mathrm{~g} \mathrm{C} \mathrm{m}^{-2} \mathrm{yr}^{-2}, \mathrm{P}=0.07$; Chang et al., 2015b).

\section{Simulation set-up}

Five drivers were considered for their impact on modeled NBP trend: 1) climate change, 2) rising global $\mathrm{CO}_{2}$ concentration, 3) changes of nitrogen addition (including fertilization and atmospheric deposition), 4) land-cover change related to new grassland establishment and 5) the changes in grassland management intensity, through the observed reduction of ruminant livestock density (Chang et al., 2015b). These drivers were prescribed in ORCHIDEE-GM. Harmonized climate forcing data were taken from the ERA-WATCH reanalysis for the period 1901-2010, at a spatial resolution of $25 \mathrm{~km} \times 25 \mathrm{~km}$ (Beer et al., 2014). Global atmospheric $\mathrm{CO}_{2}$ concentration was from the combination of ice core records and atmospheric observations assembled by Keeling et al. (2009 and update). Yearly gridded mineral fertilizer and manure nitrogen application rates for grasslands in the European Union (EU27) were estimated by the CAPRI model (Leip et al., 2011, 2014) based on combined information from different data sources such as Eurostat, FAOstat and OECD, and spatially dis-aggregated using the methodology described by Leip et al. (2008). Gridded atmospheric nitrogen deposition rates for Europe from the European Monitoring \& Evaluation Program (EMEP) data set were downloaded from the EU-PF7 GHG-Europe project (data available at http://gaia.agraria.unitus.it/ghg-europe/data/others-data) with the decadal means linearly interpolated to annual values.

Maps of changing grassland management intensity at $25 \mathrm{~km}$ resolution were constructed to drive the model with yearly changes in relative management intensity (fraction of extensively 
versus intensively managed grasslands) from 1961 to 2010, constrained by the total forage requirement of grass-fed livestock numbers (see Chang et al., 2015b for a detailed explanation of the calculation of the forage requirement and the diagnostic of the fraction of animals that receive complementary crop feed products). These maps were incorporated into the HILDA land-cover data set (Fuchs et al., 2013) to form enhanced historic land-cover maps delineating grassland management intensity and land-cover transitions (Chang et al., 2015b). Here if a fraction of grasslands in a $25 \mathrm{~km}$ grid cell is converted into another biome, it is no longer counted in the simulated NBP of grasslands, even though ORCHIDEE-GM simulates the C balance of the new biome. If a fraction of new grassland is created in a grid cell it is incorporated into the NBP by calculating at each time step the $\mathrm{C}$ balance of soils from the previous ecosystem to which new litter input from grassland is added.

The management intensity maps used above are constrained by the total forage requirement of grass-fed livestock numbers converted from the metabolizable energy (ME) requirement. The calculation of ME requirement depends on animal performance data such as liveweight and average daily milk production for each animal category (see Supporting Information Text S1 from Chang et al., 2015b), and a typical energy density of the feed suggested by IPCC (2006) is applied to convert energy requirement to forage requirement for the whole period 19612010. An assumption underlying the above calculations is that both ruminant diet composition (i.e., the fraction of arable crop-feed, crop by-products, and grass forage) and feed conversion efficiency (i.e., the animals' efficiency at converting feed mass into increases of the desired animal products such as meat and milk; referred to as FCE hereafter) are kept constant during the period 1961-2010. However, feedstuffs (including arable crop and crop by-products used to feed farm animals) have varied in the past, and FCE is changing due to the improved and balanced feeding practices and improved breeding which enable more of the feed to go to meat and milk production rather than to maintenance of the animals (Bouwman et al., 2005). 
By applying a simple feed model (Ciais et al., 2007), grain-feed consumption per ruminant animal (including maize and other cereal grain used as feedstuff) is estimated to have been increasing rapidly over the past two decades (see Supporting Information Text S1 for detail), which indicates a possible decrease in the fraction of grass forage in ruminant diet (i.e., a decline in grass-based feed consumption per ruminant animal; here, grass-based feed includes fresh grass, hay and silage) during the same period. However, the fraction of grass-based feed in the ruminant diet cannot be calculated simply by subtracting feedstuff fractions in ruminant diet, because 1) the feedstuffs considered in this study are not complete; and 2) the simple feed model developed by Ciais et al. (2007) is purely diagnostic (based on animal and production data and a set of rules) thus it cannot produce by itself an increasing share of cropbased feed (unless it is in the input data). In addition, data on the past development of FCE do not exist for all European countries.

Given: 1) the increasing grain-feed consumption per ruminant livestock, and 2) the possible growth of FCE (Bouwman et al., 2005), we can make a new assumption to account for their impact on changes in total grass forage requirement and further on changes in grassland management intensity during the two most recent decades. The above two facts together are assumed to be fully responsible for the increase in meat and milk productivities of ruminant livestock after 1991, which implies the meat and milk productivities of ruminant livestock are kept constant in the calculation of the ME requirement (dashed lines in Fig. S1 as an example of beef cattle and cows). The new estimate of ME requirement is then used to calculate the observed grass-fed livestock numbers (dashed lines in Fig. S2), and further, to establish the new maps of changing grassland management intensity considering changes in crop-based feed per animal and FCE. The newly calculated observed grass-fed livestock numbers show a stronger decline (-25\% in Livestock Units, LU) compared to the ones that do not consider the increase in crop-based feed consumption per animal and the growth in FCE (-18\% in LU). 
These new management intensity maps were also incorporated into the HILDA land-cover data set (Fuchs et al., 2013) to form a new version (Version 2) of the enhanced historic landcover maps delineating grassland management intensity. The original maps with constant ruminant diet composition and FCE from Chang et al. (2015b) will be referred as Version 1 hereafter.

To assess the contribution of each of the five drivers (management intensity, land-cover change that forms new grasslands, climate change, rising $\mathrm{CO}_{2}$ and changes in nitrogen addition) and possible interactions between them, we generated a series of ORCHIDEE-GM factorial simulations where one driver remains fixed while the others vary during the period 1991-2010. The simulation protocol is shown in Fig. 1. For the spin-up and the historic simulation (before 1991), the simulation was carried out exactly as detailed by Chang et al. (2015b) so that carbon stocks and fluxes in the starting year are already out of equilibrium, accounting for previous management, climate, nitrogen and $\mathrm{CO}_{2}$ history. ORCHIDEE-GM was then run on each grid point at $25 \mathrm{~km}$ resolution during the period 1991-2010 forced by increasing $\mathrm{CO}_{2}$, observed climate variability and nitrogen addition, with the adaptive management change algorithm described by Chang et al. (2015a), gridded land-cover change and annual changes in grassland management, but with constant ruminant diet composition and FCE (Version 1). The simulation with all drivers varying defines the control experiment $\left(E_{C T L}\right)$. All the factorial sensitivity simulations are carried out for the period 1991-2010, starting from the same state (year 1991) as in $E_{C T L}$ (e.g., soil and vegetation carbon pools, optimal animal stocking rates $\left(S_{\text {opt }}\right)$, and management intensity maps). In each factorial simulation (E1 to E5; Fig. 1), one of the five drivers is held constant at its value in year 1991, while all other drivers vary as in the control run. In the case of the "constant climate" driver $(E 1)$, in order to keep interannual variability, we cycled the climate fields from years 1991 to 1995 in a loop. Another set of simulations (Set-2, indicated with a prime, viz: $E_{C T L}{ }^{\prime}$ and $E 1^{\prime}$ to 
E5') were conducted with the same protocol described above, but using the grassland management intensity maps Version 2. Differences between the two sets of simulations allow us to assess the contribution of each of the five drivers over the full range of uncertainty due to the time-variable ruminant diet composition and FCE. All results from simulation Set-2 (i.e., using Version 2 of the historic management and land-cover change maps; $E_{C T L}{ }^{\prime}$ and $E 1^{\prime}$ to $\left.E 5^{\prime}\right)$ will be marked “in Set-2".

Trends in the drivers during past two decades

During the period 1991-2010, mean annual temperature increased in Europe. The fastest rates were found in southern Spain and southeastern Europe (Bulgaria and Romania), where the warming rate was $0.7{ }^{\circ} \mathrm{C}$ per decade (Fig. S3a). Concurrently, total annual precipitation increased in many regions of Europe, but a decline in precipitation occurred in the west of Ireland, north of Spain, southern France, and the west of Italy and Austria (Fig. S3b).

Large amount of nitrogen fertilizer (more than $60 \mathrm{~kg} \mathrm{~N} \mathrm{ha}^{-1} \mathrm{yr}^{-1}$ typically) have been applied to grassland in Germany, the Netherlands, Belgium, Luxembourg, France and Ireland, whereas application rates have remained low in other regions (mostly less than $40 \mathrm{~kg} \mathrm{~N} \mathrm{ha}^{-1}$ $\mathrm{yr}^{-1}$; see Fig. S1 of Chang et al., 2015a). A decrease in nitrogen fertilization during the period 1991-2000 is present in the gridded nitrogen addition maps used as input to ORCHIDEE-GM (Fig. S3c). According to the European Monitoring \& Evaluation Programme (EMEP) data set cited above, atmospheric nitrogen deposition rates for Europe increased over part of western Europe during the period 1991-2000, but decreased over eastern Europe for the same period (Fig. S3d). 
According to the HILDA land-cover data set, the area of grassland remained fairly stable during the period 1991-2000 in northern and western Europe, but increased in Portugal, Spain, Italy and eastern Europe countries; it decreased in Slovenia (Fig. S3e). In parallel, a decline in the area of grassland in the Czech Republic is shown in this satellite-derived data set, but this may not be real, because an extension in pasture during the period 1990-2000 may be expected due to government policies to keep farmland managed as pasture wherever possible (EEA, 2005). Ruminant livestock numbers have been reduced by $17 \%$ during the period 1991-2010 in Europe (EU28 plus Norway and Switzerland; FAOstat). Large reductions took place in eastern European countries (Fig. S3f) in response to the major political changes which happened in the early 1990s. The reduction in ruminant livestock numbers as well as the change in grassland area during the past two decades has mainly driven a transition from intensively managed grasslands to more extensively managed ones (Fig. S3g). This transition is even more severe (Fig. S3h) when the lower grass forage requirement is considered (i.e., less grass-fed livestock numbers; dashed line in Fig. S2), i.e., the possible decrease of grassfeed fraction in ruminant diet (given the increasing grain-feed consumption per ruminant animal; Fig. S4c) and the growth in FCE (Bouwman et al., 2005).

\section{Carbon balance of European grasslands}

The net ecosystem production (NEP) is defined hereafter as the difference between gross primary production (GPP) and ecosystem respiration $\left(R_{\text {eco }}\right)$ as suggested by Chapin et al. (2006):

$$
N E P=G P P-R_{\text {eсо }}
$$


where $R_{\text {eco }}$ is the respiration of all organisms including autotrophic respiration $\left(R_{a}\right)$ by primary producers and heterotrophic respiration $\left(R_{h}\right)$ by heterotrophic organisms (microbes in animals' digestive systems, and microbes in soils). Since net primary production (NPP) is defined as GPP minus $R_{a}$, NEP thus can also be expressed as:

$N E P=N P P-R_{h}$

$\mathrm{R}_{\mathrm{h}}$ simulated by ORCHIDEE-GM is defined by heterotrophic respiration caused by grazing animals (microbes living in animals' digestive systems) and by soil microbes. A positive NEP value indicates a net removal (sink) of atmospheric $\mathrm{CO}_{2}$. Note that in ORCHIDEE-GM there is no explicit representation of microbial biomass but rather the model uses first order kinetics to represent the decomposition of organic matter (Krinner et al., 2005).

NBP denotes the total rate of $\mathrm{C}$ accumulation (or loss) from ecosystems at large spatial scales (e.g., a grid cell of $25 \mathrm{~km}$ or a region), and is defined by:

$$
N B P=N E P+C_{\text {input }}-C_{\text {export }}
$$

where $C_{\text {input }}$ is the flux of $\mathrm{C}$ entering the grassland ecosystem through manure and/or slurry application, and $C_{\text {export }}$ is the total $\mathrm{C}$ lost from the grassland ecosystem through plant biomass export (mowing), and $\mathrm{CH}_{4}$ emissions by grazing animals. $C_{\text {export }}$ through milk production and animal body-mass increase is not determined and will be neglected for the calculation of NBP, which has only marginal effect on the NBP estimate (Chang et al., 2015b). It must be noted that $\mathrm{C}$ lost through dissolved organic (DOC) and carbonate-borne inorganic (carbonate-borne DIC) leaching to rivers is not determined and will also be neglected for this study in the estimation of NBP, whereas biogenic DIC (formed by $\mathrm{CO}_{2}$ from soil respiration, including $R_{a}$ by root and $R_{h}$ by heterotrophic organisms; Kindler et al., 2011) has been implicitly accounted for in the simulated $R_{a}$ and $R_{h}$ fluxes to the atmosphere. 
304 The net effect of a factor or driver $x$, is defined as the difference of NBP trend between the control simulation and each factorial simulation, $\Delta_{x}$, as:

306

$$
\Delta_{x}=N \dot{B} P_{C T L}-N \dot{B} P_{x}
$$

where $N \dot{B} P_{C T L}$ is the NBP linear trend during 1991-2010 from the control simulation where all 308 drivers including $x$ are varied, and $N \dot{B} P_{x}$ is the NBP linear trend of simulation $x$ where only 309 this driver remains fixed. Therefore, $\Delta_{\text {climate, }} \Delta_{C O 2}, \Delta_{\text {nitrogen }}, \Delta_{L C C}$ and $\Delta_{\text {management }}$ are here the individual effects of changes in climate, $\mathrm{CO}_{2}$, nitrogen fertilization, grassland area (new grasslands produced from land-cover change; $L C C$ ) and in management intensity on the NBP linear trend. The sum of individual effects can be less than or more than the effect of all the

313 factors taken together, due to non-linear interactions, and a residual, non-attributed, is defined 314 as $\Delta_{\text {residual }}$. The same attribution method was also used to determine the effect of each factor on the trends of NEP (which can be divided into NPP and $R_{h}$ ), $C_{\text {input }}$ and $C_{\text {export }}$. 


\section{Results}

During the past two decades, NBP of European grasslands simulated by ORCHIDEE-GM has increased at mean rate of 1.8 to 2.0 (in Set-2) $\mathrm{g} \mathrm{C} \mathrm{m}^{-2} \mathrm{yr}^{-2}$ (Table 1). Given a decline of carbon input from organic fertilizers $\left(C_{\text {input }}\right.$; Table 1 and Fig. $\left.2 b\right)$, this increasing NBP must come from an enhanced $\mathrm{CO}_{2}$ fixation (NEP) and/or the reduction of carbon exported as forage and $\mathrm{CH}_{4}$ emissions by grazing animals ( $C_{\text {export }}$; Table 1 and Fig. 2 b). The trend in NEP is derived from the trend of NPP minus the one in $R_{h}$ (Table 1 and Fig. 2a). A more intense increase in NBP $\left(2.0 \mathrm{~g} \mathrm{C} \mathrm{m}^{-2} \mathrm{yer}^{-2}\right)$ found in simulation Set-2 mainly resulted from the faster decrease of $C_{\text {export }}$ (with a rate of $-1.2 \mathrm{~g} \mathrm{C} \mathrm{m}^{-2} \mathrm{yr}^{-2}$; Table 1) caused by the stronger decrease in total forage requirement when accounting for the possible decrease of grass-feed fraction in ruminant diet and the growth in FCE.

Attribution of NBP trends to different drivers

All drivers considered in this study have the overall effect of increasing NBP (positive trend) for the whole European grassland ecosystem, during the period 1991-2010 (Table 1; Fig. 3). The key result is that changes in grassland management intensity make the largest contribution to the average NBP trend, namely: $0.65-0.88$ (in Set-2) $\mathrm{g} \mathrm{C} \mathrm{m}^{-2} \mathrm{yr}^{-2}$, about $36 \%$ $43 \%$ (in Set-2) of the trend due to all drivers. Management intensity changes alone are 
estimated to have enhanced soil carbon stocks by 164 - 214 (in Set-2) Tg C in 20 years over $1.3 \times 10^{6} \mathrm{~km}^{2}$ grassland (i.e., $0.23-0.30$ (in Set-2) $\mathrm{Mg} \mathrm{CO}_{2} \mathrm{ha}^{-1} \mathrm{yr}^{-1}$ when converted to the $\mathrm{C}$ sequestration per hectare of grassland). Newly established grassland (increase of grassland area) caused a comparable but lower NBP positive trend of 0.48 (in Set-2) $-0.51 \mathrm{~g} \mathrm{C} \mathrm{m}^{-2} \mathrm{yr}^{-2}$ ( $24 \%$ (in Set-2) $-28 \%$ of the trend due to all drivers). The increase in NBP attributed to increasing $\mathrm{CO}_{2}$ and climate change is 0.54 (in Set-2) - $0.55 \mathrm{~g} \mathrm{C} \mathrm{m}^{-2} \mathrm{yr}^{-2}$ (27\% (in Set-2) - 30\% of the trend due to all drivers) and 0.54 (in Set-2) $-0.56 \mathrm{~g} \mathrm{C} \mathrm{m}^{-2} \mathrm{yr}^{-2}(27 \%$ (in Set-2) - 31\% of the trend due to all drivers) respectively. The net effect of changes of nitrogen addition is only marginal ( $2 \%$ of the trend due to all drivers). The sum of NBP trends attributed to each driver is larger than the overall NBP trend caused by all drivers, leaving a residual term (about $22 \%$ (in Set-2) $-26 \%$ of the trend due to all drivers). This residual is due to negative interactions between the effects of the different drivers.

Trends of grassland management intensity are also the largest factor explaining $C_{\text {export }}$ trends (Table 1). Less intensively managed grassland (Figs S3g and $\mathrm{S} 3 \mathrm{~h}$ ) tends to reduce $C_{\text {export }}$ because average stocking rates decrease, which enhances NBP by higher litter-fall and soil carbon storage. Climate change and rising $\mathrm{CO}_{2}$ concentration both have a positive effect on NEP trends, by enhancing NPP in excess of $R_{h}$, but they also tend to increase $C_{\text {export }}$ due to a higher NPP being available for forage. Grassland establishment (land-cover change from cropland/forest to grassland) has a moderate and positive effect on NEP, however, because $R_{h}$ decreases more than NPP (Table 1 ). This lower $R_{h}$ in newly established grassland is due to the usually lower soil carbon storage of the source land cover, which is usually cropland (Post \& Kwon, 2000; Guo \& Gifford, 2002). This result depends on the source ecosystem and on the simulation by ORCHIDEE of its soil C stock. In ORCHIDEE, croplands are harvested so that only a small fraction of biomass returns to the soil; this tends to make soil C stocks lower than those in grasslands. 
Figure 4 shows the spatial distribution of the simulated trends in NBP across European grasslands during 1991-2010 from simulation Set-1 (the spatial pattern from simulation Set-2 is very similar to that of simulation Set-1). The simulated trend of NBP is positive over $80 \%$ of European grasslands. After aggregation into the major agricultural regions defined in Table S1 (for details see Olesen \& Bindi, 2002), the largest positive NBP trends appear over northeastern, and eastern (Figs 3 and 4) Europe, where decreasing management intensity and grassland establishment are the major causes of positive NBP trends. Positive NBP trends larger than $2.0 \mathrm{~g} \mathrm{C} \mathrm{m}^{-2} \mathrm{yr}^{-2}$ were also found in the British Isles and southeastern Europe, where changes in grassland management intensity play the most important role in explaining positive NBP trends. In the British Isles climate change has the largest positive effect compared to other regions of Europe (Figs 3 and 5a). It is noteworthy that in the British Isles, the sum of the five effects is $49 \%$ (in Set-2) - 50\% larger than the NBP trend obtained in the control simulation $\left(N \dot{B} P_{C T L}\right)$, suggesting a strong negative effect due to their interactions (Fig. 3). Not all the regions show an increasing NBP, and we obtained a decline of NBP (negative trend) in northwest Germany, France, Spain and southwest Romania (Fig. 4). A moderate NBP increase was simulated in alpine regions attributed to the effect of rising $\mathrm{CO}_{2}$ and changes in management intensity.

Within the five drivers considered in this study, changes in management intensity (mainly changing from intensively managed grasslands to extensively managed ones; Chang et al., 2015b) is clearly a major factor causing NBP to increase in those regions where it did (e.g., the British Isles, alpine regions, and eastern EU countries; Figs 3 and 5d). It caused 
simultaneously a decline in NEP which forced NBP to decrease (Fig. 6b), but caused an even stronger reduction of $C_{\text {export }}$, which compensates for decreased NEP and results in a net positive trend in NBP (Fig. 6d). Grassland establishment diagnosed from high resolution landcover change satellite data has a positive effect on NBP trends over regions where an increase 392 of grassland area happened (Portugal, northeastern, southeastern and eastern European 393 countries, except the Czech Republic; Fig. S3e), but also can have a negative effect on NBP 394 trends, as in Finland (Fig. 5c), because the soil C stock of the source ecosystem (forest in Finland) is larger than that of grassland and during 2001-2010 the newly established grassland in Finland was mainly converted from forest. Regionally, climate change can have either a positive or a negative effect on NBP trends (Fig. 5a), mainly through its effect on NEP. This effect can be seen from the similar spatial patterns of NEP trends and NBP trends due to climate change (Fig. 6a). The difference between NBP and NEP trend patterns are located in the most productive grasslands such as in Denmark, the Netherlands, and Belgium, where enhanced $C_{\text {export }}$ offsets or even exceeds the effects of enhanced NEP, thus causing a neutral, 402 or negative, effect of climate change on NBP in those regions. Rising $\mathrm{CO}_{2}$ concentration has a 403 moderate and positive effect all over Europe, whereas changes in nitrogen fertilization only 404 have a marginal effect on NBP trends (Fig. 5b). 
In this study, we attributed the NBP trend over European grasslands to its driving factors through a series of simulations of the ORCHIDEE-GM model separately quantifying the effect of each factor. In summary, four of the five factors considered in this study (except nitrogen addition) resulted into an overall positive effect on the NBP trend, but with different spatial patterns, magnitudes and mechanisms.

Climate change during the past two decades was simulated to cause an increase in NBP over European grassland as a whole, by increasing NPP more than $R_{h}$ (Table 1). However, the effect of recent climate trends can be positive or negative in different regions (Fig. 6a). For example, climate change induced a positive trend of NBP in the Nordic countries and the British Isles, likely from temperature warming, which enhances plant growth and extends the growing-season length in cold environments (Fig. S5). Our modeled positive effect of climate change on productivity (NPP) in the British Isles is consistent with the increasing aboveground live biomass from 1982 to 2006 derived from remote sensing products, which shows positive correlation with annual mean temperature (Xia et al., 2014). In regions where productivity is limited by water stress (Le Houerou et al., 1988; Knapp et al., 2001; Nippert et al., 2006), a decline in precipitation by more than $75 \mathrm{~mm} \mathrm{yr}^{-1}$ per decade (such as in north Spain, southern France and northeastern Italy, Fig. S3b) or a strong warming by more than 0.7 ${ }^{\circ} \mathrm{C}$ per decade (such as in Romania and north Bulgaria) cause drought conditions that reduce productivity and furthermore reduce NBP (Fig. 6a).

Elevated $\mathrm{CO}_{2}$ concentration has the dual effect of increasing leaf photosynthesis and reducing stomatal conductance, thus indirectly increasing soil moisture in unsaturated soils. These effects increase water-use efficiency (Rötter \& van de Geijn, 1999) and reduce the 
consumption of soil moisture by plant transpiration (Soussana \& Luescher, 2007). In our simulation, rising $\mathrm{CO}_{2}$ concentration causes a $4.5 \%$ increase in grassland water-use efficiency (defined as the ratio of GPP to transpiration) during the two most recent decades. This increase is calculated from the simulation E1 in which the climate of 1991-1995 is recycled, but $\mathrm{CO}_{2}$ concentration rises (Fig. 1). Increases in productivity of temperate grassland stimulated by rising $\mathrm{CO}_{2}$ concentration has been observed in FACE experiments (e.g., BioCON and Swiss FACE; Ainsworth et al., 2003; Ainsworth \& Long, 2005) and also been simulated by ORCHIDEE-GM (Chang et al., 2015a). In a separate test, ORCHIDEE-GM simulated an increase in aboveground dry matter production of $\mathrm{C} 3$ grass of $10.7 \%$ under elevated $\mathrm{CO}_{2}$ of $550 \mathrm{ppm}$ (Chang et al., 2015), which is close to that from FACE experiments, e.g., the increase of $10.5 \%$ observed by Ainsworth \& Long (2005). However, trends and variability in temperature and precipitation, as well as nitrogen limitation, will all interact with the effects of elevated $\mathrm{CO}_{2}$ in the future to determine actual changes in grassland productivity in response to $\mathrm{CO}_{2}$ (Jones \& Donnelly, 2004; Soussana \& Luescher, 2007). The residual effect on NBP trends found in this study (Table 1, Fig. 3) may be partly attributed to these interactions.

Application of nitrogen to grassland improves soil nitrogen availability, leading to higher nitrogen concentration in plant leaves, thus enhancing plant growth and productivity (Frink et al., 1999). ORCHIDEE-GM accounts for the positive effect of nitrogen addition on photosynthesis (Chang et al., 2015a). However, the effect of nitrogen addition remains marginal, because: 1) the rates of change in nitrogen addition (including fertilization and atmospheric deposition) are small over most European grasslands (within $\pm 6 \%$ per decade, Fig. S5b); or 2) nitrogen addition rate is already high throughout the period (e.g., over $100 \mathrm{~kg}$ $\mathrm{N} \mathrm{ha}^{-1} \mathrm{yr}^{-1}$ in the south of Ireland, France, the Netherlands and eastern Germany; Fig. S6a) in the regions with higher rates of change (more than $6 \%$ per decade, Fig. S6b). As a result, the 
net effect of changes in nitrogen addition (including fertilization and atmospheric deposition) on NBP trends is found to be only marginal. However, this finding may not reflect reality, since our model has only a very simple parameterization of the effects of nitrogen on photosynthesis (Chang et al., 2015a). In fact, omitting nitrogen addition from our model could also have effect on allocation (Poorter et al., 2012), and possibly affect soil organic decomposition and hence heterotrophic respiration (see review by Janssens et al., 2010 for forest).

Note that in our simulations, climate change, rising $\mathrm{CO}_{2}$ concentration and changes in nitrogen addition all impact NBP trends only through their indirect effect on NPP. The NPP change (increase/decrease) will cause a trend of fresh organic $\mathrm{C}$ availability to the three soil carbon pools of ORCHIDEE-GM, thus affecting $R_{h}$. In our model, $R_{h}$ depends on the soil organic C formed during the historical period (pre-1991), and on soil temperature and moisture trends. Overall $R_{h}$ tracks the NPP change, but with a lag. As a result, the nonsynchronous evolution of NPP and $R_{h}$ causes the NEP trend (and further the NBP trend). However, several other processes that could affect $R_{h}$ are omitted from our model: 1) the dependence of $R_{h}$ not only on soil organic $\mathrm{C}$ availability, but also on microbes which are assumed to be the direct producer of $R_{h}$ and whose activity can be temperature dependent (Allison et al., 2010); 2) the priming effect that emphasizes that increased inputs of fresh $\mathrm{C}$ (e.g., increased NPP due to climate change, rising $\mathrm{CO}_{2}$ and nitrogen addition) could stimulate soil microbes to decompose old soil organic matter (Kuzyakov et al., 2000; Kuzyakov, 2010); although an experiment on grassland soil in central France suggested high nutrient availability might reduce the priming effect, thus increase the mean residence time of soil $\mathrm{C}$ (Fontaine et al., 2011); 3) elevated $\mathrm{CO}_{2}$ might affect soil microbial community structure (e.g., Janus et al., 2005; Carney et al., 2007; Guenet et al., 2012) and possibly enzyme activities (though conflicting effects have been reported; Freeman et al., 2004), might further impact soil 
organic $\mathrm{C}$ decomposition. The soil microbial community structure could alter the temperature sensitivity of $R_{h}$ (Bradford et al., 2008), and the enzyme activities that are directly responsible for $R_{h}$. We need better models of soil $\mathrm{C}$ cycling and the representation of these microbial mechanisms should be a high priority in future model development. The CLM microbial model (Wieder et al., 2013) shows one way forward.

To avoid the negative side-effects of some farming practices, since 1962 the European Union (EU) has provided various incentives to farmers through the Common Agricultural Policy (European CAP). In 1984 the European Community introduced milk production quotas that contributed to a reduction in the dairy cow population in Europe. This was followed in 1991 by the Nitrates Directive (91/676/EEC) that restricted the application of animal manure in “nitrate vulnerable zones" (46.7\% of EU-27 land area in 2012; European Commission, 2013) to a maximum of $170 \mathrm{~kg} \mathrm{~N} \mathrm{ha}^{-1} \mathrm{yr}^{-1}$, effectively capping livestock density in pastures at some 1.7 livestock units (LU) per hectare (Annex 1 in Webb et al., 2011). In 1992, the incentives of CAP shifted from price support to direct aid payments to farmers who withdraw land from production and further limit stocking levels. As a result of these policies, the livestock numbers in Europe have decreased. In addition, major political changes in eastern and central Europe also resulted in wet grasslands being abandoned (Joyce, 2014). The European-wide livestock numbers declined by more than 17\% during the period 1991-2010 (FAOstat), reducing the requirement for grass forage and for the grassland $\mathrm{C}$ balance, less forage means less C export and thus increasing NBP. Our simulation is forced by the observed decrease of grass-fed livestock numbers (decline by 18\% - 25\% (in Set-2); Figs S1 and S2) in each European region, and takes into account the NBP response to a less intensive grassland management through its constraint that the total forage requirement of grass-fed livestock must be satisfied by grass NPP (cut and grazed). Without harvest by mowing or grazing, grasslands with less animals can have higher leaf area index (LAI), thus higher NPP than 
more intensively managed ones (Joyce, 2014; also see Chang et al., 2015b). In this study, we simulated an annual mean LAI of extensively managed grassland $26 \%$ higher than that of intensively managed grassland over Europe (data averaged for the period 1991-2010). The extra $\mathrm{C}$ taken up would be accumulated in soil as litter instead of being exported as forage. Litter has a relatively longer turnover time than forage (most forage $\mathrm{C}$ is consumed then returned to atmosphere within one year). As a result, the changes in grassland management in Europe, characterized by changing from intensively to extensively managed grassland (Fig. S2; Figs S3f, g and h) are able to cause enhanced sequestration of $\mathrm{C}$ in soil (NBP increase). Furthermore, during the transition from intensively to extensively managed grassland, nitrogen accumulated in managed grassland soils (e.g., due to fertilization) may maintain a high productivity (i.e., NPP) for some years. This residual effect of nitrogen fertilization on productivity was not taken into account because the nitrogen-effects on photosynthesis in ORCHIDEE-GM (Chang et al., 2015a) will immediately stop when grassland is converted to extensive management. In this case, our model may underestimate the NPP increase caused by decline in management intensity, and further underestimate the positive trend of NEP and NBP in the control simulation $\left(N \dot{B} P_{C T L}\right)$. It implies the effect of changes in management intensity in reality could be even larger than that estimated here (given by Eqn 4: $N \dot{B} P_{C T L}$ $N \dot{B} P_{\text {management }}$, about $36 \%-43 \%$ (in Set-2) of the trend due to all drivers). Thus again, fully accounting for the nitrogen cycle is required to produce better estimates of the grassland $\mathrm{C}$ balance and its trend. Nevertheless, a large portion of the NBP trend $(36 \%-43 \%$ of the trend due to all drivers) can be attributed to the reduction of grassland management intensity in Europe, that is probably caused by changes in policy and socio-economic influences. As fas as we are aware this is the first instance of a modeling study revealing the impact of policy on the $\mathrm{C}$ balance of European grasslands. 
529 ORCHIDEE-GM estimates an average NBP of 19 to 21 (in Set-2) $\pm 7 \mathrm{gC} \mathrm{m}^{-2} \mathrm{yr}^{-1}$ in the most recent two decades -- a cumulative $\mathrm{C}$ sink of 1.8 to 1.9 (in Set-2) \pm 0.7 gigatonnes (Gt) $\mathrm{CO}_{2}$ over about $1.3 \times 10^{6} \mathrm{~km}^{2}$ for European grasslands during 1991-2010 (EU28 plus Norway and Switzerland). This amount offsets about $10 \%$ of total greenhouse gases (GHGs) emissions in the whole agricultural sector during this period (a total of $17.3 \mathrm{Gt}^{\mathrm{CO}_{2}}$ equivalent from 19912010 including $\mathrm{CO}_{2}, \mathrm{CH}_{4}$ and $\mathrm{N}_{2} \mathrm{O}$ emissions; data from FAOstat). With respect to European grassland ecosystems, changes in grassland management alone were estimated to have enhanced the soil $\mathrm{C}$ sequestration during the 20 -year period studied by $0.60-0.79$ (in Set-2) Gt $\mathrm{CO}_{2}$ and to have simultaneously reduced $\mathrm{CH}_{4}$ and $\mathrm{N}_{2} \mathrm{O}$ emissions by $0.42-0.48$ (in Set-2)

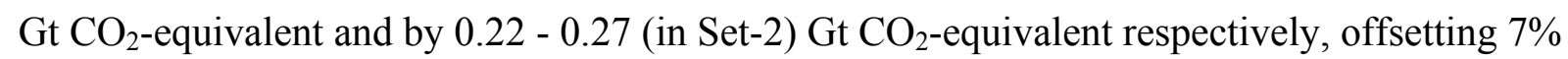
- 9\% (in Set-2) of GHG emissions in the whole agricultural sector during this period, making a substantial contribution to climate change mitigation (Ripple et al., 2014).

The $\mathrm{C}$ sequestration enhanced by changes in grassland management alone $(0.23-0.30 \mathrm{Mg}$ $\mathrm{CO}_{2} \mathrm{ha}^{-1} \mathrm{yr}^{-1}$ ) is close to the $\mathrm{C}$ sequestration potential from optimizing grazing management for rangeland estimated by Henderson et al. (2015), which is $0.17-0.32 \mathrm{Mg} \mathrm{CO}_{2} \mathrm{ha}^{-1} \mathrm{yr}^{-1}$ (to be consistent in regions considered by Henderson et al. (2015), values in western Europe and in eastern Europe and Russia were used), but higher than that for pasture in the same estimation $\left(0.03-0.05 \mathrm{Mg} \mathrm{CO}_{2} \mathrm{ha}^{-1} \mathrm{yr}^{-1}\right)$. It is noteworthy that the area of amenable grassland in Henderson et al., 2015 is only 13\% of grassland area in our simulation. Our estimation is also within the range of the global mean $\mathrm{C}$ sequestration potential due to grazing management (per hectare bases) reported by Lal (2004; $0.18-0.55 \mathrm{Mg} \mathrm{CO}_{2} \mathrm{ha}^{-1} \mathrm{yr}^{-1}$ ) and Smith et al. (2008; 0.11-0.81 $\mathrm{Mg} \mathrm{CO}_{2} \mathrm{ha}^{-1} \mathrm{yr}^{-1}$ ), while the value from Smith et al. (2008) considered a broader range of practices (grazing, fertilization and fire). Furthermore, the differences between our estimate and that from literature above should be kept in mind: 1) in this study, the $\mathrm{C}$ sequestration enhanced by changes in management intensity accounts for climate 
change, rising $\mathrm{CO}_{2}$ and a simple management change constrained simply by historic grass forage requirement; 2) Henderson et al. (2015) estimated C sequestration potential that could be achieved by optimizing grazing management based on assumed grazing management scenarios, and considered climate change at $0.5^{\circ}$ resolution; 3) the $\mathrm{C}$ sequestration potential estimated by Lal (2004) and Smith et al. (2008) are data-based (e.g., based on a small number of field studies), but didn't include the climate and $\mathrm{CO}_{2}$ perturbation (i.e., they did not use gridded simulations accounting for climate gradients across a domain). Thus our estimate and the previous estimates above could be quite complementary allowing a better view to be developed of the role of grassland management on the $\mathrm{C}$ balance and further on GHG mitigation.

Soil carbon stocks increased because of decreased management intensity in our control simulation (originating from the combination of reduced ruminant livestock numbers and the changes in grassland area, where only the new grasslands creation were considered; Fig. S3e to h). Carbon sequestration efficiency due to changes of ruminant livestock density can thus be calculated as the ratio between NBP trend due to changes in management $\left(\Delta_{\text {management }}\right.$, see 'Attribution method of NBP trends' for detail) and trend of livestock density (Table 2). Here, $\Delta_{\text {management }}$ is the individual effect of changes in grassland management intensity on the NBP linear trend; livestock density over grassland is calculated as the ratio of grass-fed livestock numbers to grassland area; and carbon sequestration efficiency due to changes of ruminant livestock density measures how much extra $\mathrm{C}$ can be sequestrated in grassland soil per each LU reduction of livestock numbers. Averaged over European grasslands, a unit LU reduction of livestock numbers is able to enhance soil C sequestration by 1016 (in Set-2) - $1131 \mathrm{~kg} \mathrm{C}$ per year (i.e., with carbon sequestration efficiency of 1016 (in Set-2) - $1131 \mathrm{~kg} \mathrm{C} \mathrm{LU}^{-1} \mathrm{yr}^{-1}$ ). This reduction indicates a substantial contribution to GHG mitigation (Ripple et al., 2014). High sequestration efficiency was found in the Nordic countries, the British Isles, alpine 
regions, southeastern and eastern regions, suggesting grassland ecosystems in these regions

580 can benefit more, with regards to GHG mitigation, from each unit of livestock numbers 581 reduction. However, the sequestration efficiency in the Nordic countries, the British Isles, and 582 alpine regions from the simulation Set-1 are not given, and should be neglected because the 583 too-low trends in livestock density (e.g., lower than $-0.2 \mathrm{LU} \mathrm{km}^{-2} \mathrm{yr}^{-1}$ ) might cause 584 unrealistically high sequestration efficiency. Grassland ecosystems in western, Mediterranean, 585 and northeastern regions of Europe can also benefit from livestock number reduction of 586 moderate magnitude. 
587 Acknowledgement: We gratefully acknowledge funding from the European Union Seventh 588 Framework Programme FP7/2007-2013 under grants $\mathrm{N}^{\circ} 266018$ (AnimalChange) and $\mathrm{N}^{\circ}$ 589603864 (HELIX). We greatly thank Dr. John Gash for his effort on English language editing. 


\section{Reference:}

Ainsworth EA, Davey PA, Hymus GJ, et al. (2003) Is stimulation of leaf photosynthesis by elevated carbon dioxide concentration maintained in the long term? A test with Lolium perenne grown for 10 years at two nitrogen fertilization levels under Free Air $\mathrm{CO}_{2}$ Enrichment (FACE). Plant Cell and Environment, 26, 705-714.

Ainsworth EA, Long SP (2005) What have we learned from 15 years of free-air $\mathrm{CO}_{2}$ enrichment (FACE)? A meta-analytic review of the responses of photosynthesis, canopy. New Phytologist, 165, 351-371.

Allison SD, Wallenstein MD, Bradford MA (2010) Soil-carbon response to warming dependent on microbial physiology. Nature Geoscience, 3, 336-340.

Beer C, Weber U, Tomelleri E, Carvalhais N, Mahecha M, Reichstein M (2014) Harmonized European Long-Term Climate Data for Assessing the Effect of Changing Temporal Variability on Land-Atmosphere $\mathrm{CO}_{2}$ Fluxes. Journal of Climate, 27, 4815-4834.

Bouwman AF, Van der Hoek KW, Eickhout B, Soenario I (2005) Exploring changes in world ruminant production systems. Agricultural Systems, 84, 121-153.

Bradford MA, Davies CA, Frey SD, et al. (2008) Thermal adaptation of soil microbial respiration to elevated temperature. Ecology Letters, 11, 1316-1327.

Buchmann N, Schulze ED (1999) Net $\mathrm{CO}_{2}$ and $\mathrm{H}_{2} \mathrm{O}$ fluxes of terrestrial ecosystems. Global Biogeochemical Cycles, 13, 751-760.

Carney KM, Hungate BA, Drake BG, Megonigal JP (2007) Altered soil microbial community at elevated $\mathrm{CO} 2$ leads to loss of soil carbon. Proceedings of the National Academy of Sciences of the United States of America, 104, 4990-4995. 
Chang JF, Ciais P, Viovy N, Vuichard N, Sultan B, Soussana J-F (2015b) The greenhouse gas balance of European grasslands. Global Change Biology, doi:10.1111/gcb.12998.

Chang JF, Viovy N, Vuichard N, et al. (2013) Incorporating grassland management in ORCHIDEE: model description and evaluation at 11 eddy-covariance sites in Europe. Geoscientific Model Development, 6, 2165-2181.

Chang JF, Viovy N, Vuichard N, et al. (2015a) Modeled changes in potential grassland productivity and in ruminant livestock density in Europe over 1961-2010. PLoS One, 10, e0127554, doi: 10.1371/journal.pone.0127554.

Chapin FS, III, Woodwell GM, Randerson JT, et al. (2006) Reconciling carbon-cycle concepts, terminology, and methods. Ecosystems, 9, 1041-1050.

Ciais P, Bousquet P, Freibauer A, Naegler T (2007) Horizontal displacement of carbon associated with agriculture and its impacts on atmospheric $\mathrm{CO}_{2}$. Global Biogeochemical Cycles, 21, GB2014, doi:10.1029/2006GB002741.

Ciais P, Reichstein M, Viovy N, et al. (2005) Europe-wide reduction in primary productivity caused by the heat and drought in 2003. Nature, 437, 529-533.

EEA (European Environment Agency) (2005) The European environment - State and outlook. 576 pp. pp. 49

European Commission (2013) Commission Staff Working Document Accompanying the document Report From The Commission To The Council And The European Parliament on the implementation of Council Directive 91/676/EEC concerning the protection of waters against pollution caused by nitrates from agricultural sources based on Member State reports for the period 2008-2011 \{COM(2013) 683 final $\}$ 
635

636

637

638

639

640

641

642

643

644

645

646

647

648

649

650

651

652

653

654

655

European Common Agricultural Policy (CAP) http://ec.europa.eu/agriculture/cap-post-2013/

FAOstat (2013) http://faostat3.fao.org

Fontaine S, Henault C, Aamor A, et al. (2011) Fungi mediate long term sequestration of carbon and nitrogen in soil through their priming effect. Soil Biology \& Biochemistry, 43, 86-96.

Freeman C, Kim SY, Lee SH, Kang $\mathrm{H}$ (2004) Effects of elevated atmospheric $\mathrm{CO}_{2}$ concentrations on soil microorganisms. Journal of Microbiology, 42, 267-277.

Frink CR, Waggoner PE, Ausubel JH (1999) Nitrogen fertilizer: Retrospect and prospect. Proceedings of the National Academy of Sciences of the United States of America, 96, $1175-1180$.

Fuchs R, Herold M, Verburg PH, Clevers JGPW (2013) A high-resolution and harmonized model approach for reconstructing and analysing historic land changes in Europe. Biogeosciences, 10, 1543-1559.

Graux AI, Gaurut M, Agabriel J, Baumont R, Delagarde R, Delaby L, Soussana J-F (2011) Development of the Pasture Simulation Model for assessing livestock production under climate change. Agriculture Ecosystems \& Environment, 144, 69-91.

Guenet B, Lenhart K, Leloup J, et al. (2012) The impact of long-term $\mathrm{CO}_{2}$ enrichment and moisture levels on soil microbial community structure and enzyme activities. Geoderma, 170, 331-336.

Guo LB, Gifford RM (2002) Soil carbon stocks and land use change: a meta analysis. Global Change Biology, 8, 345-360. 
Henderson BB, Gerber PJ, Hilinski TE, et al. (2015) Greenhouse gas mitigation potential of the world's grazing lands: Modeling soil carbon and nitrogen fluxes of mitigation practices. Agriculture, Ecosystems \& Environment, 207, 91-100.

Janus LR, Angeloni NL, McCormack J, Rier ST, Tuchman NC, Kelly JJ (2005) Elevated atmospheric $\mathrm{CO}_{2}$ alters soil microbial communities associated with trembling aspen (Populus tremuloides) roots. Microbial Ecology, 50, 102-109.

Jones MB, Donnelly A (2004) Carbon sequestration in temperate grassland ecosystems and the influence of management, climate and elevated $\mathrm{CO}_{2}$. New Phytologist, 164, 423439.

Joyce CB (2014) Ecological consequences and restoration potential of abandoned wet grasslands. Ecological Engineering, 66, 91-102.

Keeling RF, Piper SC, Bollenbacher AF, Walker JS (2009) Atmospheric $\mathrm{CO}_{2}$ records from sites in the SIO air sampling network. In Trends: A Compendium of Data on Global Change. Carbon Dioxide Information Analysis Center, Oak Ridge National Laboratory, U.S. Department of Energy, Oak Ridge, Tenn., U.S.A. doi: 10.3334/CDIAC/atg.035.

Kindler R, Siemens J, Kaiser K, et al. (2011) Dissolved carbon leaching from soil is a crucial component of the net ecosystem carbon balance. Global Change Biology, 17, 11671185.

Knapp AK, Briggs JM, Koelliker JK (2001) Frequency and extent of water limitation to primary production in a mesic temperate grassland. Ecosystems, 4, 19-28. 
677 Krinner G, Viovy N, de Noblet-Ducoudre N, et al. (2005) A dynamic global vegetation model

678

679

680

681

682

683

684

685

686

687

688

689

690

691

692

693

694

695

696

697 for studies of the coupled atmosphere-biosphere system. Global Biogeochemical Cycles, 19, GB1015, doi: 10.1029/2003GB002199.

Kuzyakov Y (2010) Priming effects: Interactions between living and dead organic matter. Soil Biology \& Biochemistry, 42, 1363-1371.

Kuzyakov Y, Friedel JK, Stahr K (2000) Review of mechanisms and quantification of priming effects. Soil Biology \& Biochemistry, 32, 1485-1498.

Lal R (2004) Soil carbon sequestration to mitigate climate change. Geoderma, 123, 1-22.

Le Bauer DS, Treseder KK (2008) Nitrogen limitation of net primary productivity in terrestrial ecosystems is globally distributed. Ecology, 89, 371-379.

Le Houerou HN, Bingham RL, Skerbek W (1988) Relationship between the variability of primary production and the variability of annual precipitation in world arid lands. Journal of Arid Environments, 15, 1-18.

Leip A, Britz W, Weiss F, de Vries W (2011) Farm, land, and soil nitrogen budgets for agriculture in Europe calculated with CAPRI. Environmental Pollution, 159, 32433253.

Leip A, Marchi G, Koeble R, Kempen M, Britz W, Li C (2008) Linking an economic model for European agriculture with a mechanistic model to estimate nitrogen and carbon losses from arable soils in Europe. Biogeosciences, 5, 73-94.

Leip A, Weiss F, Lesschen JP, Westhoek H (2014) The nitrogen footprint of food products in the European Union. Journal of Agricultural Science, 152, S20-S33. 
Melillo JM, McGuire AD, Kicklighter DW, Moore B, Vorosmarty CJ, Schloss AL (1993) Global climate-change and terrestrial net primary production. Nature, 363, 234-240.

Nippert JB, Knapp AK, Briggs JM (2006) Intra-annual rainfall variability and grassland productivity: can the past predict the future? Plant Ecology, 184, 65-74.

\section{Nitrates Directive (91/676/EEC) http://eur-lex.europa.eu/}

Olesen JE, Bindi M (2002) Consequences of climate change for European agricultural productivity, land use and policy. European Journal of Agronomy, 16, 239-262.

Piao S, Friedlingstein P, Ciais P, de Noblet-Ducoudré N, Labat D, Zaehle S (2007) Changes in climate and land use have a larger direct impact than rising $\mathrm{CO}_{2}$ on global river runoff trends. Proceedings of the National Academy of Sciences of the United States of America, 104, 15242-15247.

Poorter H, Niklas KJ, Reich PB, Oleksyn J, Poot P, Mommer L (2012) Biomass allocation to leaves, stems and roots: meta-analyses of interspecific variation and environmental control. New Phytologist, 193, 30-50.

Post WM, Kwon KC (2000) Soil carbon sequestration and land-use change: processes and potential. Global Change Biology, 6, 317-327.

Riedo M, Grub A, Rosset M, Fuhrer J (1998) A pasture simulation model for dry matter production, and fluxes of carbon, nitrogen, water and energy. Ecological Modelling, 105, $141-183$.

Ripple WJ, Smith P, Haberl H, Montzka SA, McAlpine C, Boucher DH (2014) COMMENTARY: Ruminants, climate change and climate policy. Nature Climate Change, 4, 2-5. 
Rotter R, Van de Geijn SC (1999) Climate change effects on plant growth, crop yield and livestock. Climatic Change, 43, 651-681.

Rustad LE, Campbell JL, Marion GM, et al. (2000) A meta-analysis of the response of soil respiration, net nitrogen mineralization, and aboveground plant growth to experimental ecosystem warming. Oecologia, 126, 543-562.

Schulze ED, Heimann M (1998) Carbon and water exchange of terrestrial systems, in: Asian change in the context of global change, vol. 3, IGBP Series, edited by: Galloway, J. N. and Melillo, J., Cambridge University Press, Cambridge, 145-161.

Smith P, Martino D, Cai Z, et al. (2008) Greenhouse gas mitigation in agriculture. Philosophical Transactions of the Royal Society B-Biological Sciences, 363, 789-813.

Soussana JF, Allard V, Pilegaard K, et al. (2007) Full accounting of the greenhouse gas $\left(\mathrm{CO}_{2}\right.$, $\mathrm{N}_{2} \mathrm{O}, \mathrm{CH}_{4}$ ) budget of nine European grassland sites. Agriculture Ecosystems \& Environment, 121, 121-134.

Soussana JF, Luescher A (2007) Temperate grasslands and global atmospheric change: a review. Grass and Forage Science, 62, 127-134.

Vuichard N, Ciais P, Viovy N, Calanca P, Soussana J-F (2007a) Estimating the greenhouse gas fluxes of European grasslands with a process-based model: 2. Simulations at the continental level. Global Biogeochemical Cycles, 21, GB1005, doi:10.1029/2005GB002612

Vuichard N, Soussana J-F, Ciais P, et al. (2007b) Estimating the greenhouse gas fluxes of European grasslands with a process-based model: 1. Model evaluation from in situ measurements. Global Biogeochemical Cycles, 21, GB1004, doi:10.1029/2005GB002611. 
Webb J, Sorensen P, Velthof GL, et al. (2011) Study on variation of manure N efficiency throughout Europe. AEA Technology plc, Didcot, 114 pp.

Wieder WR, Bonan GB, Allison SD (2013) Global soil carbon projections are improved by modelling microbial processes. Nature Climate Change, 3, 909-912.

Xia J, Liu S, Liang S, Chen Y, Xu W, Yuan W (2014) Spatio-Temporal Patterns and Climate Variables Controlling of Biomass Carbon Stock of Global Grassland Ecosystems from 1982 to 2006. Remote Sensing, 6, 1783-1802.

Xia J, Wan S (2008) Global response patterns of terrestrial plant species to nitrogen addition. New Phytologist, 179, 428-439. 


\section{Supporting Information Legends}

754

755

756

757

758

759

760

761

762

763

764

765

766

767

768

769

770

771

772

773

Text S1. The changes in feedstuffs for ruminants.

Table S1. Major agricultural regions in Europe (Olesen \& Bindi, 2002).

Figure S1. The evolution of meat productivity of beef cattle and milk productivity of cows in Europe. Data are averaged for EU28 plus Norway and Switzerland. Solid lines indicate the productivities derived from FAOstat; dashed lines are the constant productivities of ruminant livestock in the new calculation of ME requirement assuming that the growth in feed conversion efficiency is consistent with the increase of meat and milk productivities of ruminant livestock after 1991.

Figure S2. Grass-fed livestock numbers in each of major agricultural regions and their evolution during the period 1961-2010. The numbers were converted to livestock unit (LU) based on the calculation of metabolizable energy (ME) requirement of each type of animal with variable (i.e., the growth in feed conversion efficiency is consistent to the increase of meat and milk productivities of ruminant livestock after 1991; dashed lines) or constant (solid lines) feed conversion efficiency.

Figure S3. Spatial distribution of the changing rate (linear trends) during the period 19912010 in: (a) mean annual temperature, (b) total annual precipitation, (c) nitrogen fertilization, (d) atmospheric nitrogen deposition, (e) grassland area, (f) ruminant livestock numbers and (g) in fraction of intensively managed grassland in total grassland area with constant feed conversion efficiency (FCE) or (h) with assumed changes in FCE. The changing rate in (c) nitrogen fertilization and (d), atmospheric nitrogen deposition are estimated for the period 1991-2000, because in the database they are assumed to be constant from 2000 till 2010. Temperature and precipitation were from ERA-WATCH reanalysis climate forcing data at a spatial resolution of $25 \mathrm{~km}$ (Beer et al., 2014). Gridded mineral fertilizer and manure nitrogen 
application rate was estimated by the CAPRI model (Leip et al., 2011, 2014), based on combined information from official and harmonized data sources such as Eurostat, FAOstat and OECD, and spatially dis-aggregated using the methodology described by Leip et al. (2008); grassland area was extracted from the HILDA data set (Fuchs et al., 2013); ruminant livestock numbers were taken from FAOstat with annual country-averaged statistical data on major ruminant livestock numbers for dairy cows, beef cattle, sheep and goats; livestock species are converted to livestock unit (LU) based on the calculation of metabolizable energy requirement (see Supplementary Information Text S1 of Chang et al., 2015); fraction of intensively managed grassland in total grassland area is as established by Chang et al. (2015), constrained by the total forage requirement (derived from metabolizable energy requirement) of grass-fed livestock numbers.

Figure S4. Temporal evolution of (a) total feedstuff products, (b) farm animal numbers, and (c) feedstuff for ruminant and grain-feed consumption per head of ruminant during the last five decades. For the feedstuffs, cereal grains include maize and other cereals; other crop products and by-products included cakes of cereals and oilseeds, brans, and pulses; grain for cattle was the residual grain-feed for cattle after being distributed successively to poultry and pigs using the simple feed model (Ciais et al., 2007). To keep data consistency, the figure shows the total quantities from 23 countries of Europe, where data from Croatia, Czech Republic, Estonia, Latvia, Lithuania, Slovakia, and Slovenia were not included in due to the short period of data availability.

Figure S5. Shift in seasonal evolution of grassland GPP during the last two decades in the Nordic countries and the British Isles. The monthly mean GPP of grassland was simulated by ORCHIDEE-GM, aggregated and averaged over each region according to the area and the management intensity (extensively or intensively managed) of grassland in the enhanced historic land-cover maps delineating grassland management intensity (Version 1; see main 
803 1991-2000 and 2001-2010 respectively) were used. GPP: gross primary production.

804 Figure S6. (a) mean nitrogen addition rate over European grassland (including fertilization 805 and atmospheric deposition) and (b) its normalized changing rate during the period 1991806 2000. The normalized changing rate of nitrogen addition is calculated as the ratio of changing 807 rate (linear trend) to mean nitrogen addition rate. 
Table 1. Trends in NBP and its components over European grasslands during the period 1991-2010, and the effects of the drivers on these trends.

\begin{tabular}{|c|c|c|c|c|c|c|c|}
\hline & \multirow{2}{*}{$\begin{array}{l}\text { Linear trends } \\
\left(\mathrm{g} \mathrm{C} \mathrm{m}^{-2} \mathrm{yr}^{-2}\right)\end{array}$} & \multicolumn{6}{|c|}{ Effect of the drivers on the trends } \\
\hline & & Climate forcing & $\begin{array}{c}\text { Atmospheric } \mathrm{CO}_{2} \\
\text { concentration }\end{array}$ & Nitrogen addition & Grassland area & $\begin{array}{c}\text { Grassland } \\
\text { management }\end{array}$ & Residual \\
\hline$\overline{N B P}$ & $1.8 / 2.0^{\prime}$ & $0.6 / 0.5^{\prime}$ & 0.5 & 0.0 & 0.5 & $0.6 / 0.9^{\prime}$ & $0.5 / 0.4^{\prime}$ \\
\hline$N E P$ & $2.0 / 1.9^{\prime}$ & 0.9 & $0.8 / 0.7^{\prime}$ & 0.0 & 0.5 & -0.1 & $0.1 / 0.0^{\prime}$ \\
\hline$C_{\text {export }}$ & $-0.1 /-0.4^{\prime}$ & 0.3 & 0.2 & 0.0 & -0.1 & $-0.9 /-1.2^{\prime}$ & $-0.3 /-0.4^{\prime}$ \\
\hline$C_{\text {input }}$ & $-0.2 /-0.3^{\prime}$ & 0.0 & 0.0 & 0.0 & 0.0 & -0.2 & 0.0 \\
\hline$N P P$ & $4.7 / 5.0^{\prime}$ & 2.7 & $2.0 / 1.9^{\prime}$ & 0.0 & -0.2 & $0.7 / 1.0^{\prime}$ & 0.4 \\
\hline$R_{h}$ & $2.7 / 3.1^{\prime}$ & 1.8 & 1.2 & 0.0 & -0.7 & $0.8 / 1.1^{\prime}$ & $0.3 / 0.4^{\prime}$ \\
\hline
\end{tabular}
shown. NEP, net ecosystem production; $C_{\text {export }}$, carbon exported from grassland ecosystem as forage and $\mathrm{CH}_{4}$ emission; $C_{\text {input }}$, carbon input by organic fertilizer application; NPP, net primary production; $R_{h}$, heterotrophic respiration. NEP is defined as the difference between NPP and $R_{h}$, 
817 European grasslands.

\begin{tabular}{lccc}
\hline Regions & \multicolumn{1}{c}{$\Delta_{\text {management }}$} & Trends in livestock density & C sequestration efficiency \\
& $\mathrm{g} \mathrm{C} \mathrm{m}^{-2} \mathrm{yr}^{-2}$ & $\mathrm{LU} \mathrm{km}^{-2} \mathrm{yr}^{-1}$ & $\mathrm{~kg} \mathrm{C} \mathrm{LU}^{-1} \mathrm{yr}^{-1}$ \\
\hline Nordic & $0.14 / 0.19^{\prime}$ & $-0.01 /-0.21^{\prime}$ & $-* / 1612^{\prime}$ \\
British Isles & $1.24 / 1.75^{\prime}$ & $-0.17 /-0.87^{\prime}$ & $-* / 2013$ \\
Western & $0.36 / 0.55^{\prime}$ & $-0.46 /-0.75^{\prime}$ & $795 / 734^{\prime}$ \\
Mediterranean & $0.25 / 0.41^{\prime}$ & $-0.42 /-0.51^{\prime}$ & $605 / 795^{\prime}$ \\
Alpine & $0.48 / 0.75^{\prime}$ & $-0.16 /-0.49^{\prime}$ & $-* / 1539^{\prime}$ \\
North eastern & $0.90 / 1.53^{\prime}$ & $-1.07 /-1.77^{\prime}$ & $839 / 860^{\prime}$ \\
Sourth eastern & $1.82 / 1.95^{\prime}$ & $-0.96 /-1.08^{\prime}$ & $1884 / 1810^{\prime}$ \\
Eastern & $2.22 / 2.82^{\prime}$ & $-1.58 /-2.12^{\prime}$ & $1398 / 1330^{\prime}$ \\
Total & $0.65 / 0.88^{\prime}$ & $-0.58 /-0.87^{\prime}$ & $1131 / 1016^{\prime}$ \\
\hline
\end{tabular}

* Carbon sequestration efficiency is not given due to the too-low trends in both NBP and/or

819 livestock density.

Note: Values in the $\Delta_{\text {management }}$ column are the individual effects of changes in grassland management intensity on the NBP linear trend; Livestock density over grassland is calculated as the ratio of grass-fed livestock numbers to grassland area. Values without the prime (')

823 indicate the results from the simulation Set-1 accounting for the constant ruminant diet 824 composition and feed conversion efficiency; Values with the prime (') indicate the results 825 from the simulation Set-2 accounting for the varied ruminant diet composition and feed conversion efficiency (section 'Simulation set-up' and Supporting information Text S1 for

827 detail). 


\section{Figure legends}

Figure 1. Illustration of the simulation protocol and the five factors used as input data for various simulations. $E_{C T L}$ : control simulation with all factors varied; E1-E5: the factorial sensitivity simulations started from the same state (at the end of 1990) as in $E_{C T R}$, but with one of the five drivers being held constant to the value of year 1991 or cycled in a loop with the climate fields from years 1991 to 1995 (in gray background). The NBP trend during 1991-2010 from simulation $E_{C T L}$, and $E 1-E 5$ is expressed as $N \dot{B} P_{C T L}, N \dot{B} P_{\text {climate }}, N \dot{B} P_{C O 2}$, $N \dot{B} P_{\text {nitrogen }}, N \dot{B} P_{L C C}$, and $N \dot{B} P_{\text {management }}$ respectively.

Figure 2. Changes in the components of NBP ((a) NPP and $R_{h}$, (b) $C_{\text {export }}$ and $C_{\text {input }}$ ) across European grasslands during the period 1991-2010. NPP: net primary production; $R_{h}$ : heterotrophic respiration; $C_{\text {export }}$ : carbon exported from grassland ecosystem as forage; $C_{\text {input }}$ : carbon input by organic fertilizer application. Results are derived from simulation Set-1 considering constant ruminant diet composition and feed conversion efficiency.

Figure 3. The NBP trends of grassland ecosystems and the effect of each driver considered in this study. The figure shows the results for all the grassland in Europe and for grassland in each major agricultural region (region 1 to 8 as shown in the figure; also see Table S1 for detail). $N \dot{B} P_{C T L}$ is the NBP trend during 1991-2010 from the control simulation; $\Delta_{\text {climate }}, \Delta_{C O 2}$, $\Delta_{\text {nitrogen }}, \Delta_{L C C}$ and $\Delta_{\text {management }}$ are the individual effects of climate change, rising $\mathrm{CO}_{2}$ concentration, changes in nitrogen addition, in land cover (grassland area) and in grassland management intensity respectively to the NBP trend. The sum of individual effects can be less than, or more than, the effect of all the factors taken together, due to non-linear interactions, and the residual is defined as $\Delta_{\text {residual }}$. Bars filled with solid color indicate the trends and the effects from the simulation Set-1 accounting for the constant ruminant diet composition and feed conversion efficiency; bars filled with parallel lines indicate the trends and the effects from the simulation Set-2 accounting for the varied ruminant diet composition and feed 
conversion efficiency (section 'Simulation set-up' and Supporting Information Text S1 for detail).

Figure 4. The spatial distribution of linear trends in NBP during the period 1991-2010 derived from simulation Set-1 considering constant ruminant diet composition and feed conversion efficiency.

Figure 5. Spatial distribution of the trends in NBP due to: (a) climate change, (b) changes in nitrogen fertilization, (c) changes in grassland area, and (d) in grassland management intensity. Grassland management intensity in this study is given by the fraction of extensively versus intensively managed grasslands; the transition between them (i.e., changes in grassland management intensity) is constrained by the total forage requirement of grass-fed livestock numbers (see Chang et al., 2015b for detailed). Results are derived from simulation Set-1 considering constant ruminant diet composition and feed conversion efficiency. and c) climate change and (b and d) changes in grassland management intensity. Grassland management intensity in this study is given by the fraction of extensively versus intensively managed grasslands; the transition between them (i.e., changes in grassland management

870 intensity) is constrained by the total forage requirement of grass-fed livestock numbers (see 871 Chang et al., 2015b for details). Results are derived from simulation Set-1 considering constant ruminant diet composition and feed conversion efficiency. 


\begin{tabular}{|c|c|c|c|c|c|c|}
\hline & Climate forcing & $\begin{array}{c}\text { Atmospheric } \mathrm{CO}_{2} \\
\text { concentration }\end{array}$ & Nitrogen addition & Grassland area & $\begin{array}{c}\text { Grassland } \\
\text { management }\end{array}$ & NBP trend \\
\hline$E_{\text {CTL }}$ & $1991-2010$ & $1991-2010$ & $1991-2010$ & $1991-2010$ & $1991-2010$ & $N \dot{B} P_{C T L}$ \\
\hline E1 & 1991-1995 & $1991-2010$ & $1991-2010$ & $1991-2010$ & $1991-2010$ & $N \dot{B} P_{\text {climate }}$ \\
\hline E2 & $1991-2010$ & 1991 & $1991-2010$ & $1991-2010$ & $1991-2010$ & $N B P_{\mathrm{CO} 2}$ \\
\hline E3 & $1991-2010$ & $1991-2010$ & 1991 & $1991-2010$ & $1991-2010$ & $N \dot{B} P_{\text {nitrogen }}$ \\
\hline E4 & $1991-2010$ & $1991-2010$ & $1991-2010$ & 1991 & $1991-2010$ & $N \dot{B} P_{L C C}$ \\
\hline E5 & $1991-2010$ & $1991-2010$ & $1991-2010$ & $1991-2010$ & 1991 & $N \dot{B} P_{\text {management }}$ \\
\hline
\end{tabular}




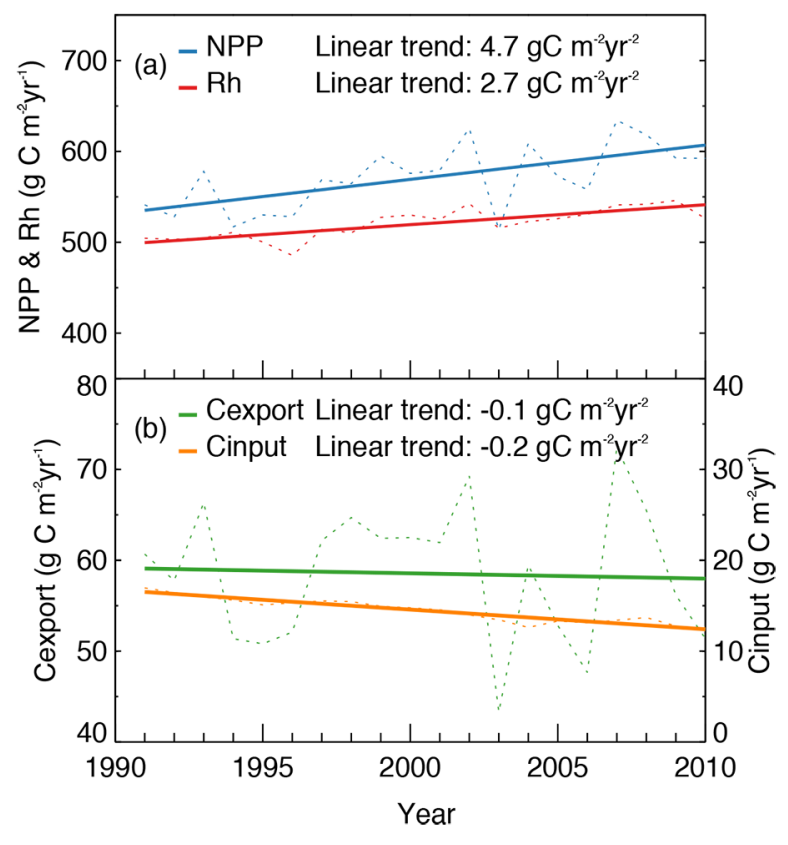




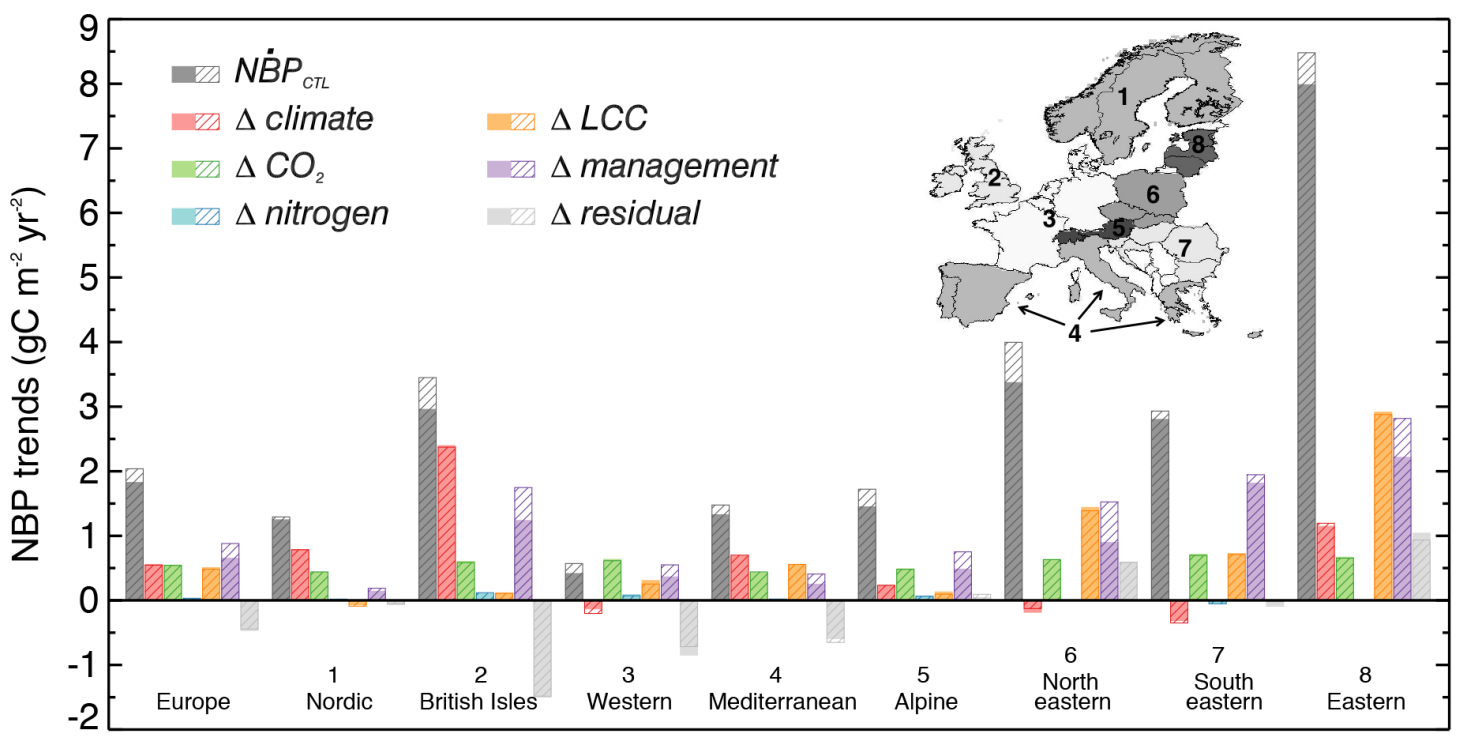




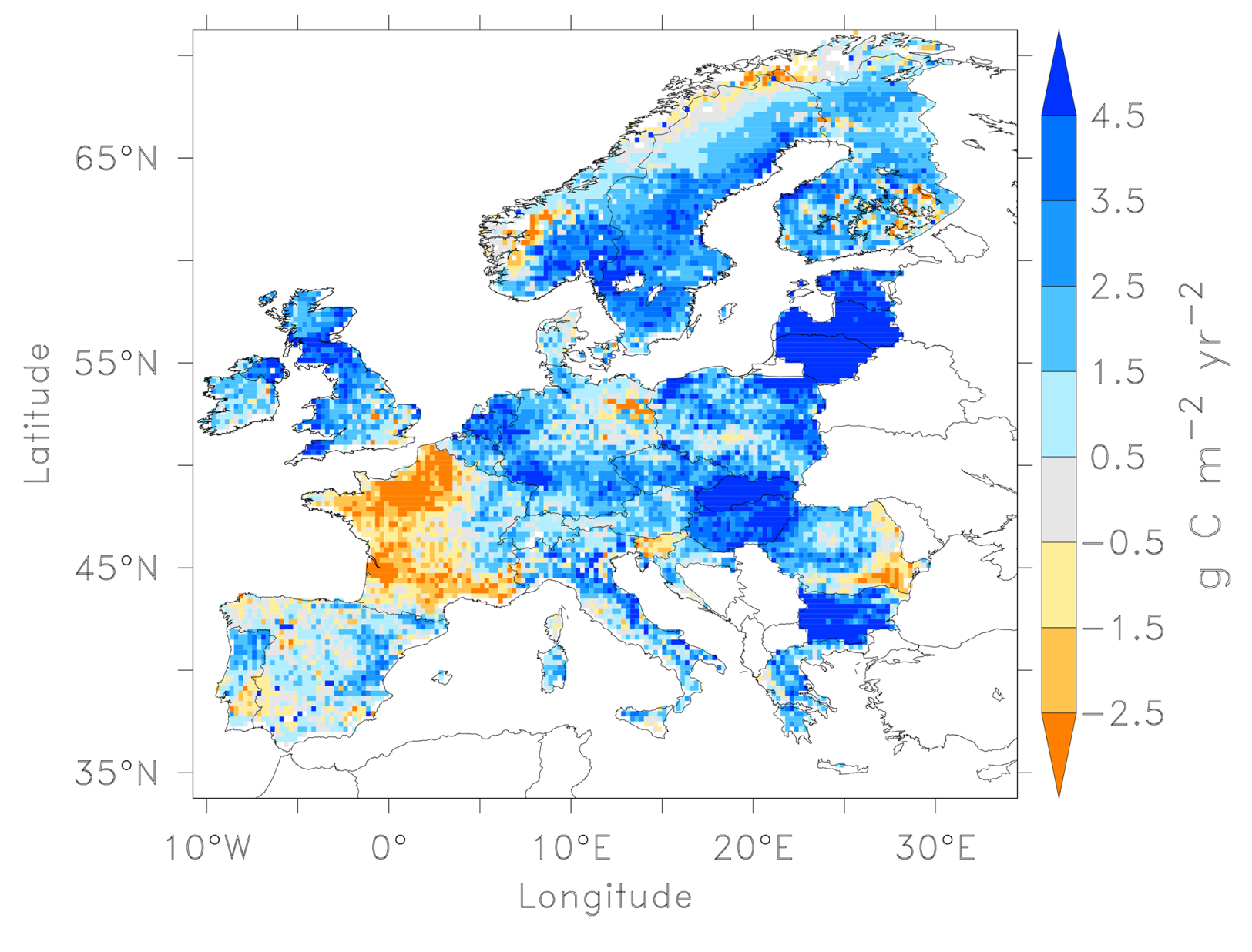

879 

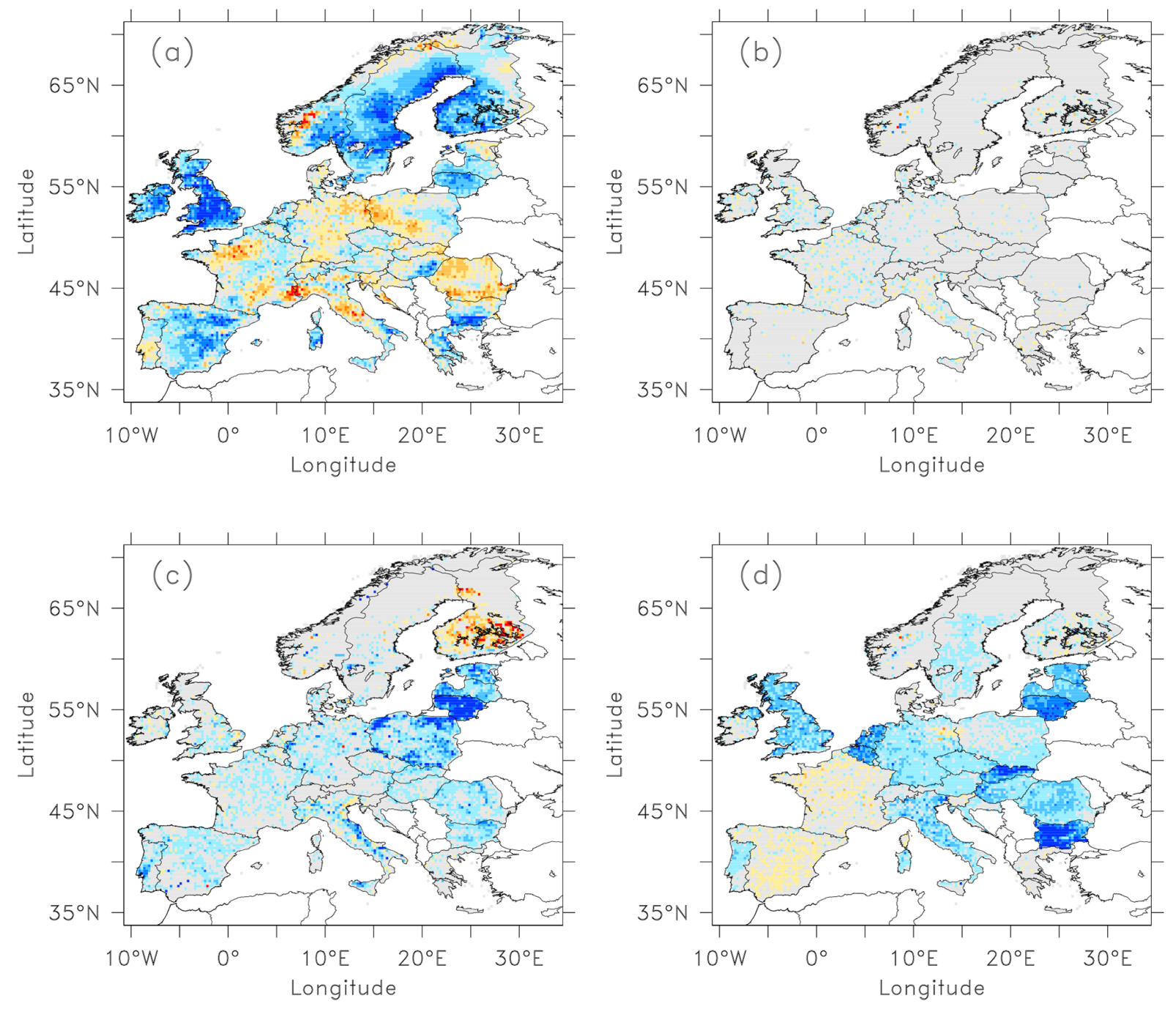

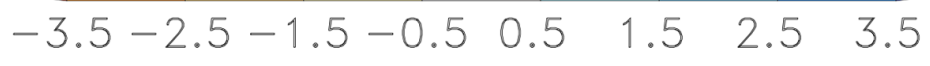$$
\text { g C m }{ }^{-2} \mathrm{yr}^{-2}
$$ 

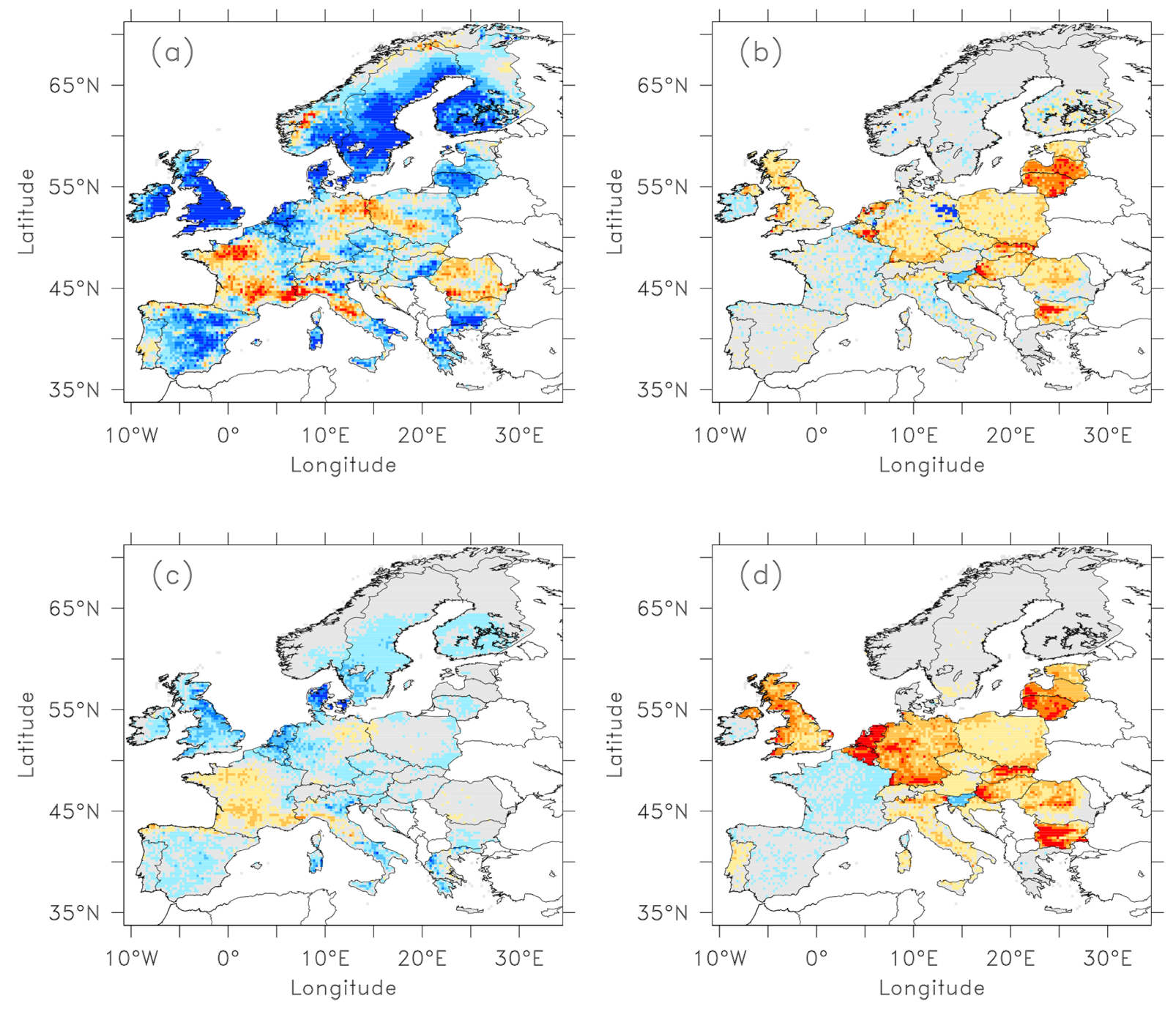